\title{
Taming the Tiger: Voting Rights and Political Instability in Latin America
}

\author{
Latin American Politics and Society, Summer 2004
}

Josep M. Colomer

ABSTRACT

This article discusses the relationship between certain institutional regulations of voting rights and elections, different levels of electoral participation, and the degree of political instability in several Latin American political experiences. A formal model specifies the hypotheses that sudden enlargements of the electorate may provoke high levels of political instability, especially under plurality and other restrictive electoral rules, while gradual enlargements of the electorate may prevent much electoral and political innovation and help stability. Empirical data illustrate these hypotheses. A historical survey identifies different patterns of political instability and stability in different countries and periods, which can be compared with the adoption of different voting rights regulations and electoral rules either encouraging or depressing turnout.

At the time of Porfirio Diaz's seventh election as president of Mexico in 1910, Francisco I. Madero called a
rebellion under the motto "Effective suffrage, no rlection." As he was leaving for exile in May 1911 , Diaz
reportedly said: "Madero has unleashed a tiger; let's see if he can control it." Madero was elected
president with broad electoral support, but less than two years later he was assassinated, and Mexico
plunged into two decades of revolution and civil war. More than 1.5 million people were killed;
approximately 12 percent of the Mexican population.-(Meyer and Sherman 1979, 511)

This article discusses the relationship between political regime stability and certain institutional regulations of voting rights and electoral participation in several past political experiences in Latin America. Political regime stability here implies only the absence of political conflicts leading to regime change, such as rebellions, coups, revolutions, and civil wars. The analysis focuses on electoral institutions with a significant influence on electoral participation, mainly the regulation of voting rights and registration procedures and the basic characteristics of electoral systems.

The main hypothesis to be discussed is that in the past, many regime crises in Latin America were fostered by the shock of sudden introductions of broad suffrage rights under exclusive electoral rules. The sudden enlargement of the incumbent electorate with new, large groups able to develop and promote new political preferences may overthrow the previously existing political equilibrium, especially under plurality and other exclusive electoral rules producing a single absolute winner-a president and his party in congress-supported by only a minority of voters and many absolute losers. In contrast to the 
instability effects of broad voting rights with exclusive electoral rules, some significant degree of political stability can be achieved by a nondemocratic regime holding elections with restrictive rules, able to exclude a majority of the population from the electorate or to incorporate different groups of voters gradually into the existing institutional framework. Alternatively, political regime stability can also be achieved on the basis of the opportunities for sharing power and introducing smoother policy changes usually created by proportional representation and other permissive and inclusive electoral rules that have been widely adopted in the region during more recent periods of democratization.

A basic assumption in the following analysis is that citizens' support or rejection of political regimes crucially depends on the type of winners they tend to produce. In particular, a single-winner, minority outcome is likely to provoke negative reactions against the institutional framework among the many absolute losers. The second part of this article will survey a number of regime crises fostered by rejections of political outcomes produced by sudden enlargements of the electorate under such restrictive institutional frameworks. Notorious cases include Argentina in 1829, 1930, and 1955; Colombia in 1857 and 1949; Mexico in 1835 and 1911; and Peru in I860 and 1968. In all these cases, as well as in other countries and periods not closely scrutinized here, the emergence of winners manufactured by restrictive electoral institutions provoked strong rejection and was followed by reactionary or military coups, civil wars, or dictatorships.

In contrast to regime crises largely provoked by sudden changes in the size and composition of the electorate, such as those just mentioned, significant stability was achieved in a number of Latin American countries during several periods of the late nineteenth and twentieth centuries by regimes that, while they held regular elections, dramatically reduced mass participation and political competition. These include, in particular, certain periods with nondemocratic but election-based political regimes in Brazil from 1824 to 1930 , Chile from 1822 to 1946 , and Mexico from 1876 to 1910 and 1929 to 1988 , as well as less durable experiences in other countries. These nondemocratic political regimes can be ranked from softer to harder, but all of them can be distinguished, in crucial institutional features, from dictatorial regimes that did not hold elections at all.

In these cases, electoral demobilization and manipulation of voters whose participation could have threatened the existing political equilibria, especially workers, indigenous people, and recent immigrants, was produced not only by the requirement of some economic or literacy conditions to receive voting rights, but also by other formal and informal institutional mechanisms that could reduce political competition. Eventually, however, also in these cases, the introduction of effective universal male suffrage provoked some dramatic regime crises; for example, in Mexico from 1911 on (as alluded to in the 
epigraph), in Brazil in 1904, and in Chile on several occasions during the nineteenth century and until 1973.

The arguments developed in this article can be put in relation to hypotheses and postulates previously presented in some classic political studies. In particular, Samuel Huntington, who focused on the role of modernization and economic development in political stability, notes that "the expansion of political participation," together with "the political backwardness of the country in terms of political institutionalization, make it difficult if not impossible for the demands upon the government to be expressed through legitimate channels and to be moderate and aggregated within the political system. Hence the rapid increase in participation gives rise to political instability" (Huntington $1908, \$ 5$ ). Taking a slightly different approach, the present article will emphasize the role of restrictive electoral institutions in the relationship between increase in participation and political instability.

The potentially destabilizing effects of enlarging the electorate and the connection of this problem with an increasing interest in institutional engineering, especially in regard to electoral rules and procedures, were also grasped by Stein Rokkan in his seminal comparative studies of political life. He notes that, in Western Europe and the United States during the late nineteenth and early twentieth centuries, the bitter debates over the two issues [districting and electoral formulas] reflect fears and resentments generated through changes in the equilibrium of political power under the impact of mass democracy: the influx of new voters altered the character of the system and a great variety of stratagems were tried out to bring it back into equilibrium. (Rokkan 1970, 155). Nevertheless, Rokkan did not include Latin America among the cases under consideration, and both Huntington and he actually made the remarks quoted here in a rather speculative manner without much elaboration.

More formally, Robert Dahl distinguishes two crucial political variables: the right to participate in elections and the liberalization of the political system (or "public contestation"), which can be assimilated with our attention to voting rights and the inclusiveness of institutional rules, respectively. Dahl, however, focuses mainly on the conditions for successful democratization and political stability, either by gradually introducing public contestation under limited voting rights (as in Britain), by enlarging voting rights while limiting public contestation (a model that would fit most of Mexico's twentieth-century experience), or by establishing fair institutional rules permitting pluralistic representation that can attract large social acceptance, the "polyarchy" (Dahl 1971, 4-9). To understand some other historical features in Latin American countries, by contrast, the following pages will identify alternative conditions prone to foster political instability. 
The analysis developed in this article draws on the distinction among three different strategies of voting rights, each of them producing different political consequences, which have been identified elsewhere in a historical and comparative perspective (Colomer 2001, chap. 2). They include the so-called Anglo model-referring mainly to the United Kingdom and the United States-which was based on a gradual allocation of voting rights to different minority groups through a slow, lengthy process of moderate reforms; and the Nordic model-corresponding to early developments in Germany and Northern European countries-which made the sudden enfranchisement of a very large electorate compatible with appreciable degrees of political stability, thanks to the introduction of proportional representation and other pluralistic institutional arrangements. In contrast to these two successful means, the so-called Latin model involved a sudden jump from a small electorate to universal men's suffrage under single-winner electoral rules provoking high electoral unpredictability and instability. Although this third framework has been applied to the analysis of a few cases in Latin Europe, the present article will expand on specific features of the problem in Latin America.1

The political and institutional implications of the analysis developed in the following pages may be diverse. From a conservative point of view, for instance, limiting the size of the electorate may be seen as an effective way to achieve some significant degree of political stability. For a revolutionary purpose, in contrast, the sudden enlargement of the electorate could be considered a favorable condition for producing radical political changes. This article pretends to illuminate the question for readers holding different normative values. It can also be held, however, that broad voting rights can be compatible with some high degree of political stability if the regime is organized with inclusive electoral institutions, such as proportional representation and absolute majority rule, able to produce encompassing winners with relatively large electoral and social support. The most recent experiences of relatively stable democracy in most countries in Latin America also seem to support this statement.

The following pages first present a formal model in which the degree of political instability depends on the size and dispersion of the electorate. Second, they provide original calculations of proportions of voters in the total population for the larger Latin American countries for several periods since independence. In addition, recently available historical evidence about voting rules, which had not yet been submitted to systematic comparative analysis, is compiled and interpreted from the perspective provided by the model and discussion. 


\section{MODELING ELECTORAL INSTABILITY}

The effects of enlarging the electorate with new groups of voters holding political preferences different from those of the incumbents can be analyzed with the help of some formal tools. Let us first assume that different political preferences, which can correspond to socioeconomic categories such as landlords, smallowners, artisans, workers, and so on, can be represented as different positions on a one-dimensional scale, such as the typical left-right axis, in such a way that different relative "distances" between voters' groups can be estimated. The assumption of a single dimension may not necessarily fit reality in some countries and periods; but it is used here as an analytical simplification, which is legitimate and useful because it compares only relative distances between groups of voters' preferences. Alternatively, it would have been possible to develop a two-dimensional model, which is also common in certain spatial analyses of political competition; but that would have produced analogous results and a more baroque and difficultto-read presentation.

Let us also assume that for each composition of the electorate, different winning coalitions of voters can be formed. For instance, if the existing electoral rules require an absolute majority of voters to make a winner, the corresponding winning coalitions will always include the position of the median voterthat is, the voter having less than a majority of voters on each side of the political space. If, however, the winner can be made by plurality rule, the winning coalition may not include the median voter among its supporters. The set of all those positions in the political space that can form a winning coalition is called the win-set.

The size of the win-set is a proxy for the unpredictability of the electoral outcome: the larger the set of potentially winning positions, the more unpredictable the electoral outcome will be. If the outcome of each single election is highly unpredictable, the series of outcomes at successive elections will be likely to create high political instability. We thus develop a simple formal analysis from the perspective that the larger the size of the win-set of a given electorate, the higher the instability of the outcomes that can be expected.

In this approach, the argument about the effects of changes in the electorate on the degrees of political instability can be synthesized the following way.

* First, the more "distant" the new voters from the initial winner, which will be catted status quo, the larger the win-set. This means, in other words, that the more the new voters' political preferences differ from those of the incumbent voters, the higher the political instability of the corresponding electoral 
outcomes that can be expected. It can be assumed, for instance, that industrial workers have preferences more different from landlords than from artisans, artisans have more different preferences from landlords than from smallowners, and so on. The formal model will allow us to make the more precise statement that the size of the win-set and therefore the degree of outcome instability tends to increase more than proportionally with the distances to the status quo introduced by new voters. With some degree of dispersion of voters' preferences, new winning positions can be located even at significantly more extreme positions on the political spectrum than the preference of the most extreme voter.

This formal finding may give a well-founded analytical grounding to traditional fears that new suffrage rights could be a slippery slope to the unknown. These fears were expressed in the past as risks that permissive regulations covering voting rights granted to workers, immigrants, or alternative ethnic groups could become occasions of "hazardous," "threatening," "extremist," or "chaotic" electoral results.

* Second, the more exclusive the electoral rule, the larger the size of the win-set and the higher the corresponding degree of outcome instability. This will be illustrated in particular by comparing sizes of win-sets in elections by the highly exclusive plurality rule with those in elections by the less exclusive simple majority rule. As analysis will show, the more exclusive the rule, the larger the set of potentially winning positions and the more unpredictable the electoral outcome will be.

* Third, the effects of political instability can be reduced by a gradual enlargement of the electorate with new groups of voters producing successive new winners at different stages in the process. Also, the introduction of new voters with political preferences located on intermediate positions among the incumbent voters may reduce the size of the win-set and the corresponding degree of potential outcome instability. Even more, if different groups of new voters are located on opposite sides of the political space regarding the status quo, they could neutralize each other and confirm the size of the previous win-set or even reinforce the stability of the status quo.

These formal findings may give well-founded analytical grounds to certain political strategies that favor a gradual introduction of new voting rights for different social groups in order to preserve some degree of political stability. They can also explain certain historical arguments about the "innocuousness" or even the potential "counterweight" effect of conceding new voting rights to some groups, especially certain fractions of peasants and bourgeois women, compared to the likely destabilizing consequences of enfranchising workers or recent immigrants. 
Figure 1. Enlarging the electorate

1.1. Three voters: A, B, C

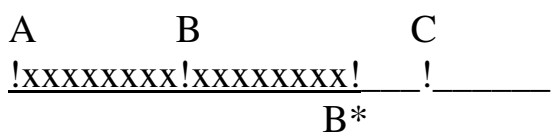

Note:

Status-quo A. Pivotal median voter B. Distance $A B=$ distance BB*. Win-set: A-B*: xxx

1.2. Five more dispersed voters: A, B, C, D, E
A $\quad$ B
$\mathrm{C}$
$\mathrm{D}, \mathrm{E}$

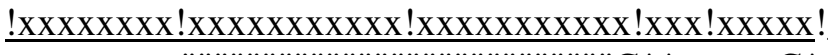

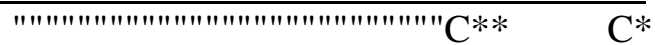

Note:

Status-quo A. Pivotal median voter C. Distance AC $=C^{*}$. Win-set from A: A-C*: xxx

Status-quo B. Pivotal median voter C. Distance BC $=\mathrm{CC} * *$. Win-set from B: B-C**: "'"'"

1.3. Five more dispersed voters with plurality rule (2/5)
A
B
$\mathrm{C}$
$\mathrm{D}, \mathrm{E}$

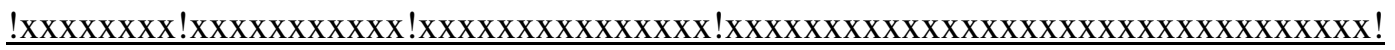

$\mathrm{D}^{*}$

Note:

Status-quo A. Distance AD = DD*. Win-set from A: A-D*: xxx

1.4. Five less dispersed voters: A, B, C, F, G

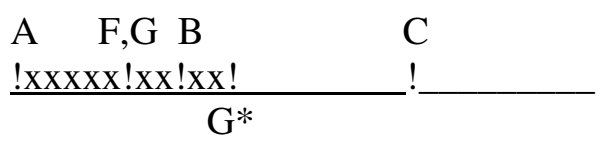

Note:

Status-quo A. Pivotal median voter G. Distance $A G=G^{*}$. Win-set from A: A-G*: $x x x$ 
Let us start the formal analysis with the simplest possible example of three voters, which can be called $A, B$, and $C$, respectively, as presented in figure 1.1 . The preference of $A$ is assumed to be the initial status quo, as may have resulted, perhaps, from an extremely small previous electorate or just from the lack of elections. The reader can figure out, for instance, that A is a group of large landowners, B represents smallowners and shopkeepers, and $\mathrm{C}$ includes artisans and other modest taxpayers. Each group can be incorporated into the electorate as a consequence of different voting rights regulations, requiring, for instance, some amount of property, income, or taxes to be given suffrage rights-as typically happened in countries holding regular political elections during the nineteenth century. Figure 1.1 suggests that the successive groups hold preferences at increasing relative distances from each other, so that $A$ is relatively closer to $B$ than $B$ is to $C$. This might reflect relatively high levels of social inequality among the groups. Different distances among groups, which can reflect social structures, values, and ideological opinions, can, of course, modify the scope of the results. But in qualitative terms, the present model can be generally valid to illustrate the type of relations developed between the variables under consideration.

For the sake of simplicity, let us assume that each group represents a similar number of voters and that a winner can be made by absolute majority; in this case, by any coalition of two of the three groups. The three possible winning coalitions are $A B, A C$, and $B C$. The two coalitions including the initial winner, A, whose preference defines the status quo, will probably be unable to introduce any change, because the members of A will resist any move from the status quo to any other position away from their preference. Only the winning coalition BC can create new winners. But in this innovative coalition, the median voter, B, is a pivotal voter, able to limit the scope of changes and define the win-set around its preference. The new winning position can be located anywhere between the status quo and the point B*, which is found around B at symmetrical distance from it to the status quo A (distance $A B=$ distance $B B^{*}$ ), as shown in the figure. This means that B can prefer, instead of the status quo A, any point between the status quo $A$ and $B$, and also any point between $B$ and $B^{*}$, because the latter will be located at a smaller distance from B's preference than the status quo. In the particular example in figure 1.1 , B* is located somewhat closer to the status quo than to $C$, thereby denying $C$ the opportunity to make its preference the winner. Thus the win-set encompasses all political positions between the status quo A and $\mathrm{B}^{*}$; in other words, the interval A-B*, as shown by the $\mathrm{X}^{\prime} \mathrm{s}$ in the figure.

Let us now compare this with the result corresponding to an enlargement of the electorate with two new voters, D and E, located an even greater distance from the incumbent voters, as presented in figure 1.2. They can represent, for instance, a group of previously disenfranchised industrial workers. 
(Two groups with the same preference are added now in order to keep an odd number of voters able to produce a winner by simple majority without a tie). This new configuration of the electorate with five voters comprises a number of winning coalitions including $A(A B C, A B D, A B E, A C D, A C E, A D E)$, which give A the opportunity to resist any move from the status quo; and some winning coalitions including $B$ ( $B C D$, $B C E, B D E)$, which will confirm the win-set $A-B^{*}$ corresponding to the previous electorate with three voters. Only the coalition CDE will be able to introduce changes. Now the median voter $\mathrm{C}$ becomes the pivotal voter, able to accept any position between the status quo $\mathrm{A}$ and $\mathrm{C}^{*}(\mathrm{AC}=\mathrm{CC} *)$.

Observe that the new win-set A-C* may include potential winners located beyond the most extreme voters' positions, in this case D and E. If, for instance, by enlarging the electorate with new voters, the distance between the most distant voters is multiplied by two, the size of the new win-set may be multiplied by three or four. The intuition behind this is that because $C$, as well as the new voters $D$ and E, holds very distant preferences from the initial status quo A, these voters can be ready to accept even highly distant winners on the other side of the spectrum because these will be located at a relatively smaller distance from them than the very distant initial status quo. The consequence is that the new winset, $\mathrm{A}-\mathrm{C}^{*}$, is huge. Some of the older voters, A and B, can really fear that the introduction of new voters, such as $D$ and $E$, may produce new outcomes at enormous distance from their preferences, thereby creating a feeling of extreme potential instability.

Now assume that, in this enlarged electorate with five relatively dispersed voters, the election can be won by simple plurality rule, requiring not an absolute majority but only more votes than any other alternative. Let us operationalize the winner by plurality at 40 percent of the vote, which means that, in the example, any coalition of two out of five voters can make a winner. (A 40 percent winner is a fairly realistic estimate for elections by plurality rule in the real world; it is consistent, for instance, with the presumption that two other candidates split the remaining 60 percent of the vote.)

The analysis can be followed in figure 1.3. Analogous to the previous examples, now all winning coalitions including A will confirm the status quo, all remaining winning coalitions including B will confirm the win-set $A-B^{*}$, and all remaining winning coalitions including $C$ will confirm the win-set $A-C *$. But the innovative winning coalition DE will produce an extremely large win-set A-D*, encompassing potential winners located at extremely distant positions from both the status quo and the most extreme voter, thereby creating overwhelming unpredictability of the outcomes and potential instability at successive elections. Almost any position can win by plurality rule, including a large variety of minority-supported alternatives, which may provoke widespread dissatisfaction among the numerous losers.

We see, thus, that with a more exclusive electoral rule, such as plurality, the size of the win-set and the corresponding degree of outcome instability increase compared to the less exclusive majority rule. 
Using Diaz's metaphor, we might say that a feeling can spread that "the tiger" is loose, he can attack anywhere, and his claws can really hurt.

Now let us consider some alternative hypotheses that could produce smaller win-sets and, therefore, higher political stability. Let us first assume that the enlargement of the electorate with new groups of voters is enforced gradually. As a first step, a relatively complex but still reduced electorate formed by $A, B$, and $C$ is established. Let us assume that this electorate endures a period sufficiently long as to create a new winner; say, for instance, the median and pivotal voter B, whose position becomes the new status quo. From this new status quo, an enlargement of the electorate, for instance with voters D and $\mathrm{E}$, will have lessdestabilizing consequences than the same enlargement would have if it were adopted suddenly while the initial status quo were still located at A, as assumed in our previous discussion. Now, with the new electorate of five dispersed voters, A, B, C, D, and E, as represented in figure 1.2, the median voter $\mathrm{C}$ becomes again the pivotal voter, able to define the win-set around his preference. But the win-set now will be defined in comparison with the status quo B (not the previous status quo A), so it will be the interval $\mathrm{B}-\mathrm{C}^{* *}\left(\mathrm{BC}=\mathrm{C} \mathrm{C}^{* *}\right)$, which is smaller than the win-set $\mathrm{A}-\mathrm{C}^{*}$ previously found. Likewise, as, at successive stages of a gradual enlargement of the electorate, new pivotal voters emerge, able to produce new status quo points away from the initial status quo A, the corresponding win-sets will be relatively reduced, and therefore the electoral results will be more predictable and less unstable than those produced by a sudden enlargement of the electorate.

Now consider the case in which the initial electorate $A B C$ is not enlarged with new voters located at more dispersed positions, as previously assumed, but with other new voters, which can be called $\mathrm{F}$ and G, whose preferences are located somewhere in between the incumbent voters; for instance, between A and $\mathrm{B}$, as shown in figure 1.4. Applying the same kind of analysis as in the previous cases, the reader can see that $\mathrm{F}$ and $\mathrm{G}$ are now the pivotal voters, because it is not possible to form a majority winning coalition without including their positions, and the new win-set is defined as the interval A-G*. As can be noted, this new win-set is even smaller than the one created by the initial electorate $A B C$, as shown by figures 1.1 and 1.4. So, in this case, the introduction of new voters actually reduces the size of the win-set and, therefore, can be expected to increase the degree of outcome stability.

The extent of this kind of moderating effect will depend on the exact position of the new voters, but in general it can be stated that the introduction of new voters not increasing the dispersion of the electorate preferences will not increase and may reduce the size of the winset; that is, the dispersion of the potential winners and the corresponding political instability. This kind of argument in favor of moderating effects of new intermediate voters was used during the nineteenth century, for instance, by 
some strategists who held that if voting rights were conceded to them, some peasants would vote as their patrons did, and most women as did their fathers and husbands.

Particularly moderating effects can also be produced by enlarging the electorate with new voters located at opposite sides of the previous win-set, as would be the case, for instance, if the electorate $A B C$ were enlarged with a voter $\mathrm{D}$ at a more extreme position on one side, as in figures 1.2 and 1.3, and also with another new voter $\mathrm{H}$ located on the other side; that is, at the left of the status quo A (not included in the figure). The new "centrist" and pivotal voter would now be B, so that there would be no possible winning coalition without $B$, and the corresponding win-set would be the small interval $A-B$, as can be easily checked out. In this case, it could be said that the introduction of the new voter $\mathrm{H}$ would have a "counterweighting" effect to the introduction of the new voter $D$, resulting from the significant distance and opposite directions of their respective preferences to the previous winners. By all the means mentioned in the last few paragraphs, it may seem possible to political strategists to "tame the tiger"; to reduce his moves within a cage, so to speak.

\section{VOTING RIGHTS IN HISTORY}

The model just presented can be illustrated with a certain amount of empirical observation. The following is only an exploratory analysis, which should be further developed and refined. Although it takes great benefit from a number of single-country stories-the typical product of the existing historiography-it proposes an explicitly comparative, theorydriven analysis, which is more characteristic of social science literature.

The basic features of regulation of voting rights and electoral procedures, including voting rights requisites, registration of electors, voluntary or compulsory vote, and secret or open ballot, for the six largest countries of Latin America are presented in table 1. Note that data are presented for election years, not including years in which legal provisions were approved but not enforced. Also, estimated percentages of voters in the total population are given at the far right column. The table looks not only at legal regulations giving voting rights to certain categories of citizens, but also at their practical consequences in promoting electoral mobilization or demobilization, thus encouraging or depressing turnout. 
Table 1. Size of the Electorate in Latin America

Country/ Voting rights requirements Electoral regulations $\begin{aligned} & \text { Voters as \% of } \\ & \text { total population }\end{aligned}$
Election years

\begin{tabular}{|c|c|c|c|}
\hline \multicolumn{4}{|l|}{ Argentina } \\
\hline 1826 & Men, age 20 or married, citizens & \multicolumn{2}{|c|}{$\begin{array}{l}\text { Voluntary registration, voluntary vote, } \\
\text { open ballot, indirect elections } 5-10\end{array}$} \\
\hline $1853-1910$ & $\begin{array}{l}\text { Men, } 17 \text { ( } 21 \text { in } 1857,18 \text { since } 1863 \\
\text { citizens }\end{array}$ & Indirect presidential elections & $1-3$ \\
\hline 1912-1930 & Men, 18 & $\begin{array}{l}\text { Automatic registration, } \\
\text { compulsory vote, secret ballot }\end{array}$ & $9-13$ \\
\hline 1946- & & & 17 \\
\hline $\begin{array}{l}1951-1965 \\
1983-1999\end{array}$ & Men and women, 18 & Direct presidential elections & $\begin{array}{l}42-45 \\
47-57\end{array}$ \\
\hline \multicolumn{4}{|l|}{ Brazil } \\
\hline$\overline{1824-1875}$ & $\begin{array}{l}\text { Men, age } 25 \text { or } 21 \text { married, } \\
\text { income, no slaves }\end{array}$ & \multirow{4}{*}{\multicolumn{2}{|c|}{$\begin{array}{lc}\text { Voluntary registration, voluntary } & \text { vote, } \\
\text { open ballot, indirect elections } & <1 \\
\text { Direct elections } & 1-3 \\
\text { Compulsory vote, secret ballot } & >10 \\
\text { Compulsory registration, compulsory }\end{array}$}} \\
\hline 1881-1930 & Men, 21, literacy & & \\
\hline 1932-1935 & Men, 18 and optional 16 & & \\
\hline 1945-1960 & Men and women, 18 & & \\
\hline 1986-2002 & $\begin{array}{l}\text { literacy } \\
\text { Men and women, } 16\end{array}$ & vote for literates, secret ballot & $\begin{array}{l}13-18 \\
44-51\end{array}$ \\
\hline \multicolumn{4}{|l|}{ Chile } \\
\hline 1822 & Men, age 25, some income & $\begin{array}{l}\text { Voluntary registration, voluntar } \\
\text { secret ballot, indirect elections }\end{array}$ & $\begin{array}{l}\text { ry vote, } \\
<5\end{array}$ \\
\hline 1828 & Men, 21 or married, some income & & $<5$ \\
\hline 1833-1871 & $\begin{array}{l}\text { Men, } 25 \text { or } 21 \text { married, } \\
\text { property or income }\end{array}$ & \multicolumn{2}{|c|}{$\begin{array}{l}\text { Open ballot, indirect presidential } \\
\text { elections }\end{array}$} \\
\hline 1874-1920 & $\begin{array}{l}\text { Men, } 25 \text { or } 21 \text { married (21 since } 18 \\
\text { literacy }\end{array}$ & & $4-5$ \\
\hline 1925-1946 & & \multirow[t]{2}{*}{ Direct presidential elections } & $5-9$ \\
\hline $1952-1958$ & Men and women, 21, literacy & & $15-17$ \\
\hline 1964-1970 & & \multirow{2}{*}{ Secret ballot, compulsory vote } & $30-33$ \\
\hline 1989-1999 & Men and women, 18 & & $38-55$ \\
\hline \multicolumn{4}{|l|}{ Colombia } \\
\hline $1833-1853$ & $\begin{array}{l}\text { Men, age } 21 \text { or married, property } \\
\text { or income }\end{array}$ & \multicolumn{2}{|c|}{$\begin{array}{l}\text { Voluntary registration, voluntary vote, } \\
\text { open ballot, indirect elections }<5\end{array}$} \\
\hline $1857-1860$ & Men, 21 & Secret ballot, direct elections & 10 \\
\hline 1864-1910 & Men, 21 , income and literacy Indir & ct elections & \\
\hline 1914-1934 & Men, 21, some income & \multirow[t]{3}{*}{ Direct elections } & $5-12$ \\
\hline 1938-1946 & Men, 21 & & $6-13$ \\
\hline 1958-2002 & Men and women, 21 (18 since 197 & & $17-22$ \\
\hline
\end{tabular}




\begin{tabular}{|c|c|c|c|}
\hline \multicolumn{4}{|l|}{ Mexico } \\
\hline$\overline{1824-1833}$ & Men, age 21 or married & \multicolumn{2}{|c|}{$\begin{array}{l}\text { Voluntary registration, voluntary vote, } \\
\text { open ballot, indirect elections }\end{array}$} \\
\hline 1857-1910 & & & $1-5$ \\
\hline 1911-1952 & Men, 20 & $\begin{array}{l}\text { Compulsory vote, secret ballot, } \\
\text { direct elections }\end{array}$ & $6-13$ \\
\hline 1955-1967 & \multirow{3}{*}{$\begin{array}{l}\text { Men and women, } 20 \\
\text { Men and women, } 18\end{array}$} & & $19-24$ \\
\hline 1970-1988 & & & $20-32$ \\
\hline $1994-2000$ & & Compulsory registration & $32-38$ \\
\hline \multicolumn{4}{|l|}{ Peru } \\
\hline 1828 & $\begin{array}{l}\text { Men, age } 21 \text { or married, } \\
\text { literacy non-indigenous }\end{array}$ & \multicolumn{2}{|c|}{$\begin{array}{l}\text { Voluntary registration, voluntary vote, } \\
\text { open ballot direct elections }\end{array}$} \\
\hline 1858 & Men, 21 & & 24 \\
\hline 1860 & $\begin{array}{l}\text { Men, } 21 \text { or married, } \\
\text { property, tax or literacy }\end{array}$ & \multicolumn{2}{|l|}{ Indirect elections } \\
\hline $1896-1920$ & Men, 21 or married, literacy & Dire & $1-3$ \\
\hline 1931 & Men, 21, literacy & Compulsory vote, secret ballot & 5 \\
\hline $1956-1963$ & Men and women, 21, literacy & & $15-18$ \\
\hline 1980-1995 & Men and women, 21 & & $26-39$ \\
\hline $2000-2001$ & Men and women, 18 & Compulsory registration & $46-49$ \\
\hline \multicolumn{4}{|c|}{$\begin{array}{l}\text { Note. Only innovative regulations are mentioned. } \\
\text { Source: Author's compilation and calculations from data in El pensamiento...1831, } \\
\text { Arosemena 1878, Vanhanen 1975, Ochoa 1987, Nohlen 1993, IDEA 1997, 2002, Katz } \\
\text { 1997, Rose 2000, Payne et al. 2002, www.georgewton.edu/pdba, www.ifes.org; and from } \\
\text { local sources for Argentina: Cantón 1973, Botana 1998; for Brazil: Leal 1949, Costa Porto } \\
\text { 1989, Graham 1990; for Chile: Valenzuela 1985; for Colombia: Bushnell 1993; for } \\
\text { Mexico: González-Casanova 1967, Cossío 1976, Becerra et al. 2000; for Peru: Basadre } \\
\text { 1980. Population data for early historical periods can be found in Mitchell 1992. }\end{array}$} \\
\hline
\end{tabular}


In order to have a standard for relative evaluation of different levels of electoral turnout, we may consider that two-figure percentages of total population usually means that most adult men participated. This estimate can be derived from the assumption that women amounted to about half the population, and children and young people-also typically excluded from voting-for about another half. Adult men would thus account for about 25 percent of the total population, so that universal male suffrage rights with majority participation would lead to turnout levels of about 12 to 13 percent of total population or, roughly speaking, more than 10 percent.

Two basic patterns can be distinguished regarding the introduction of voting rights in Latin America during the nineteenth and twentieth centuries. In accordance with the implications of the formal model previously presented, in some real cases the sudden enlargement of the electorate was followed by high political instability, especially when the enlargement was implemented under exclusive electoral rules and procedures; while in other cases a gradual strategy for the introduction of new voting rights produced higher stability in the long term. As previously remarked, it can be supposed that instability of winners, including in particular minority, extreme, and shifting presidents, may foster wide rejection of the institutional framework producing such outcomes. In contrast, institutions that produce higher stability of winners with large electoral support are likely to suffer less rejection ancl endure longer.

More specifically, in some countries, the sudden introduction of universal suffrage starting from very small electorates and under rather exclusive electoral rules produced unpredictable electoral outcomes, negative reactions from some groups against the institutions having permitted such effects, and the corresponding turmoil and regime instability. This pattern-which can be associated with the abovementioned European "Latin model"-can be illustrated with a number of experiences of elections held with broad popular suffrage and followed by conflict and authoritarian reactions in Argentina, Colombia, Mexico, and Peru. In some other countries and periods, by contrast, a slow, gradual enlargement of the electorate by giving new voting rights to different groups at different stages in time induced higher political stability in the long term. This pattern-somewhat related to the so-called Anglo model-can be illustrated in particular with some historical periods in Brazil and Chile. The mention of these examples does not mean that each country has followed a single pattern over a two-century period, since-as will be specified below-there have been periods of stability and instability in every country. The selected periods are taken only as illustrations of different paths.

\section{Mobilizing Independence}


The first pattern-a sudden introduction of broad-suffrage elections under exclusive electoral rules, inducing high political instability-was common in most Spanish American countries at the time of their independence from Spanish rule. As is well known, following the Napoleonic invasion of Spain and the abdication of King Ferdinand VII in 1808, elections for representatives to the Central junta in charge of organizing the resistance against the French were called not only on the Peninsula but also in the colonies of the Americas and the Philippines.

The elections for the junta in 1809, for new cones in 1810 and 1812, and for municipal and provincial councils in 1812-14 were all held with informal voting regulations permitting broad sectors of people to participate. More than one hundred American cities were involved in those first Spanish elections. Exclusions from the electorate were devised for those lacking an "honest livelihood," but in practice this meant that even Indians in the colonies were allowed to vote. Although exact numbers of voters are difficult to find-precisely because of the informality ancl openness of voting regulations-the information made available by a number of recent historical studies strongly suggests that many of these early elections obtained broad participation, in most cases including most adult men (Chavarri Sidera 1988; Demelas-Bohy and Guerra 1996; Posada-Carbo 1996).

Several factors that might have induced electoral mobilization can be identified in this early process. First, weak colonial structures had allowed local units derived from old kingdoms and multiethnic empires to survive, particularly in the form of Indian republics. Local communities kept some significant degree of social homogeneity, which facilitated their collective mobilization. Second, anti-Napoleonic leaders in Spain found potential support in the colonies, but the American-born creoles wanted to include "castes" in the account of the population in order to be entitled to a higher number of deputies in the Spanish cortes, thus opening electoral participation to indigenous. Third, further mobilization, led by creoles against the Spanish rule, also relied on indigenous participation in order to obtain broad support for the cause of independence. Later on, popular mobilization was also fostered by local rivalries among creole and ladino elites, as well as by resistance to Spanish, U.S., British, and French neocolonial attacks on the new republics.

This accumulation of institutional and strategic inducements provoked open and large electoral mobilizations during the period $1809-20$ in the different Spanish viceroyalties. Buenos Aires and other provinces in Rio de la Plata (which ultimately became Argentina) organized early elections with flexible regulations. Successive local regulations from 1810 on gave voting rights in Buenos Aires to all "free men" and later to all residents more than 25 years old, while in Cordoba, voting rights were given to all free men more than 18 years old, including resident foreigners and grandchildren of slaves. In 1821 , universal male suffrage for direct election of representatives was more formally established for all men older than 
20. Foreigners were excluded, but at that time, voting rights encompassed about 20 percent of the total population (Luna 1988; Chiaramonte 1995; Ternavasio 1995; Alonso 1996).

Similarly, in New Spain (which became Mexico), for the elections to both the Spanish cortes and local and provincial councils, more than six hundred electoral districts were established, most of them corresponding to traditional parishes and the Indian republics. In 1814, voting rights were given to all adult men 18 years old, or younger if married, including not only all Indians but also "patriotic foreigners" (Annino 1995, 1996).

The Crown of Portugal called elections in 1821, in a different political context but according to the same electoral regulations provided by the Spanish Constitution of 1812. In Brazil, "the elections mobilized the interest of the majority of the male adult population of the towns. There were no restrictions of race or literacy." Economic requisites were low, and could be fulfilled by all "except beggars and vagabonds. . . A Approximately half of free men 24 years old or more were in the census and, in some provinces, the number rose to 85 percent" (Graham 1995).

This early electoral mobilization was a major episode in the Spanish and Portuguese colonies' process of gaining independence. Historians register "the early existence of a relatively wide suffrage in the Hispanic world . . . in most Latin American countries the idea of an extended suffrage gained ground during the first half of the nineteenth century to an extent which has few parallels in the Western World" (Posada-Carho 1996, 6). As suggested, however, most of these contests were held with rather hazardous regulations. Open local assemblies (cabildos), as well as mixes of indirect elections with up to five levels and ancient and medieval-style lots, were widely used at different stages, while only the plurality rule was adopted for making a winner. Voting was public and cast orally at the district or parish level. Accordingly, and consistent with the general hypothesis previously presented in our model, in many cases elections were very "divisive," "hot," and "tumultuous," followed by high levels of political instability (Luna 1988; Demelas-Bohy and Guerra 1990).

\section{Participatory Clashes}

Even once the new republics had established their independence, electoral and political turmoil persisted for awhile and reemerged at later historical stages. Relevant cases illustrating this pattern can include certain historical periods in Argentina, Colombia, Mexico, and Peru. The following survey simply points out those institutional elements which, according to our model, can be considered to have strong influence on electoral results; that is, the sudden enlargement of the electorate and its mobilization, as produced by the establishment of universal (male) suffrage, automatic or compulsory registration of electors, and certain electoral procedures favoring participation (such as secret ballot), together with the use of 
exclusionary electoral rules, such as indirect elections or plurality rule. In the following, evaluations regarding high or low levels of turnout and degrees of stability or instability of political regimes will be presented in qualitative terms, but they are supported with more precise quantitative data presented in table 1 and its sources. Although references to the table will not be repeated throughout the text, the reader may want to check verbal statements with the figures there provided.

Argentina. There were at least three major attempts formally to introduce universal male suffrage in Argentina that were followed by authoritarian reactions. First, the Constitution of 1820 established universal male suffrage for those 20 years old, or younger if married. Participation rose to about 10 percent of the total population-the threshold previously identified as including most adult men. But consistent with the general hypothesis presented in the model, the experience was shortlived; in this case only for a couple of years, plagued by threats and conflicts, until the governor of Buenos Aires, Commandante Juan-Manuel Rosas, established his dictatorship, which lasted from 1829 to 1852. The Constitution of 1853 formally kept many of the previous regulations, but now the electorate was drastically reduced by requiring citizenship, at a time when immigrants were becoming an absolute majority of the population. Governors' control of voters, coercion, and so-called patriotic fraud also became routine. The subsequent degree of political stability was remarkable. After the 1880 s, Conservative governments followed one another, while political competition was fictitious or nonexistent. Actual turnout stayed at such low levels as between 1 and 3 percent of the total population for more than 50 years (Canton 1937; Botana 1977; Bethell 1993; Cibotti 1995; Sabato 1995; Negretto and Aguilar 2000).

The second attempt to establish practical effective universal male suffrage was linked to the socalled Saenz Pena law in 1912. The following new regulations were established: automatic registration as electors of all men more than 18 years old by using military censuses of the compulsory draft recently established; compulsory voting, including a criminal penalty for abstainers; secret ballot (although voters were required to sign the ballot envelope); and mechanisms for significantly reducing fraud. This set of formulas was able to promote higher electoral participation than previous regulations, which legally established broad rights to vote but submitted their exercise to strong institutional and procedural restrictions. Presidential elections were still indirect, however, while the House of Deputies was electee! by plurality rule and limited vote; that is, a set of formulas that could heavily distort electoral results, in spite of parliamentary pressures to adopt proportional representation.

Turnout rose again to two-figure proportions of total population, but-as could be expected from our general hypothesis-this experience was conflictive and short-lived. In the first presidential election 
with the new rules, in 1916, the candidate of the opposition Radical Party, Hipolito Irigoyen, unexpectedly and narrowly won the presidential office in the electoral college for the first time, and was reelected in 1928. But only two years later, a military coup supported by the Conservatives dissolved the constitutional government and established a new dictatorship (Botana 1977; Canton et al. 1990; Ansaldi 1993).

The third time universal suffrage was introduced in Argentina was in 1946, opening the vote to women for the following election. The huge electoral mobilization promoted by President Juan Domingo Peron and his party, which rose to more than 40 percent of the total population, together with the restoration of the distorting electoral rules previously mentioned, soon provoked the high concentration of power in a single party and the subsequent social clash. This was followed by a series of military coups in 1955,1966 , and 1976, with interludes of isolated elections with restrictive regulations.

Colombia. A number of attempts to introduce universal male suffrage suddenly in Colombia were also followed by violent conflicts. After the initial experiment of Gran Colombia, which included Ne-W Granada and Venezuela, a relatively stable political framework was established only for New Granada, soon known as Colombia, after 1832 . Elections were held regularly, but voting regulations required property or income, thereby excluding the great majority of the adult male population. This election-based, nondemocratic regime established "a record of outward stability superior to that of most of Latin America" for about 20 years (Bushnell 1993, 74). However, the first election by plurality of a Liberal president, Jose Hilario Lopez, who won with a minority of votes over several Conservative candidates who split the vote, provoked a Conservative rebellion, which ended with a Liberal victory and the replacement of the previous regime.

The Constitution of 1853 established, for the first time, universal male suffrage for those 21 years old, while keeping indirect elections and introducing secret ballot for president, congress, governors, local governments, and judges. In the first presidential election in 1857, participation rose to about 10 percent of the total population-the threshold previously mentioned. A new minority victory by plurality rule, this time by a Conservative, Mariano Ospina Rodriguez, provoked a new rebellion, led now by the Liberals, which ended in civil war.

Subsequently, voting regulations were established by each of the nine state governments, most of which reintroduced economic or literacy qualifications. Local bosses held pervasive control of electoral results and fraud. In 1900, a military coup supported by the Conservatives established even more stringent rules, leading to "the longest period of internal political stability of its [Colombia's] independent history." A slow increase in participation again reached two figures, so that "by the 1930 s Colombia was 
on the verge of being acclaimed as an exemplary Latin American democracy" (Bushnell 1993, 155; see also Arosemena 1878; Deas 1996; Posada-Carbo 1997).

This process culminated in the formal establishment of universal male suffrage for the second time in 1936. But again-and in accordance with our general hypothesis-the experience was short-lived. In contrast to two Liberal presidents elected by majority, in 1946 a minority Conservative candidate won by plurality over two vote-divided Liberal candidates-again an inefficient result produced by plurality rule. The victory of Mariano Ospina Ferez triggered a replication of the Liberal rebellion that overthrew his forebear in the previous century. The period from 1946 to 1957, which is known in Colombia as Ia violencia, included a new military coup and the subsequent dictatorship (Posada-Carbo 2000).

Regular elections with universal suffrage have been held in Colombia since 1958, with women included. This new democratic experience was initially protected from traditional violent conflicts and civil wars by the National Front pact between Conservatives and Liberals to share power and alternate in the presidency. The agreement secured partial stability for awhile. Bipartisan collusions, however, eventually became an exclusionary mechanism for other groups. Internal regime stability has been maintained thanks to very low levels of electoral participation relative to other current Latin American democracies. Turnout-including women-is only about 20 percent of the total population; this is partly induced by restrictive institutional mechanisms, such as voluntary registration and voluntary vote. But high levels of antisystem political violence in Colombia have also persisted during this most recent period.

Mexico. The case of Mexico also shows blatantly the effects of different voting rights regulations and electoral rules. As mentioned above, the process of independence was characterized by high levels of popular mobilization with informal, permissive voting regulations and frequent conflicts. In particular, indigenous people were electorally mobilized, first by the Spaniards against the French, then by the créoles against the Spaniards, and later by rival créole leaders trying to obtain advantage from enclaves of local support. The Constitution of 1824 allowed the states to adopt their own voting rights regulations, which in some cases included economic requirements. But mobilizing leaders, indirect elections, and complex combinations of property, ethnic, religious, and foreign relations issues induced outcome instability and created widespread feelings of social threat and frequent turmoil. Soon General Antonio Lopez de Santa Anna established an authoritarian regime, which, although it formally regulated voting rights with income requirements, actually ruled as a dictatorship during most of the period 1833-55 (Di Telia 1994; Warren 1996).

Broad voting rights according to the 1824 Constitution were reestablished in 1857, although actual levels of electoral participation remained relatively low. That period includes the reform led by 
Benito Juarez, which actually was a three-year civil war, as well as an ephemeral, French-supported empire violently fought by the republicans, and a series of rebellions against the elected rulers in the form of antireelection demands, frequently abated by martial laws. Antireelectionist General Porfirio Diaz won militarily in 1876 and established a nondemocratic regime based on his own successive reelection that lasted nearly 35 years. As in comparable political regimes in the region-and in accordance with our general hypothesis-voters' demobilization and administrative centralization produced significant political stability. But Diaz's high concentration of power and the corresponding political exclusion eventually led to his overthrow from outside the system (Perry 1979; Krauze 1984; Emmerich 1985; Guerra 1985).

As noted in the epigraph, in 1910 Francisco I. Madero called a rebellion in favor of "effective suffrage and no reelection." After introducing the secret ballot, Madero got to mobilize broad layers of people for his own presidential election, but violence soon engulfed most of the country for about 20 years-once again in correspondence to our model. Although the Constitution of 1917 gave the central government more political power to quell violent conflicts among regional and local caudillos, the following decade still saw extreme turmoil, including a number of political leaders' assassinations. Only after Plutarco Elias Galles organized a unified national political party in 1929 did Mexico return to a period of stability, but this again was achieved at the cost of suppressing political competition. The successor of Calles's party, the Party of Institutional Revolution (PRI), formally created in 1946, dominated until the late 1980 s, thanks to a system of regular elections based on universal suffrage but also on the absence of electoral rivalry, systematic corruption, and widespread electoral fraud (Brandenburg 1964; Scott 1964; Meyer and Sherman 1979; Meyer 1985; Colomer 1998).

Peru. Broadly participatory elections were held in Peru relatively early, under the impulse of large popular mobilizations for independence. The Constitution of 1828 gave voting rights to those men 25 years old or married who fulfilled prerequisites of property and literacy. The latter restriction was not actually applied, however, largely because rival leaders competed for additional support among the indigenous population. Thus, large numbers of Indians, who constituted close to 60 percent of the total population, voted. A new regulation in 1839 legalized this practice and encouraged broader participation. As a consequence, turnout was rather high and kept rising, up to one-fourth of the total population, comparatively a very high proportion for male-restricted elections. Numerous candidates emerged to challenge the incumbent representatives, but indirect elections produced distorted results and claims of electoral fraud. As could be expected according to our general hypothesis, moreover, "violence marred elections in Peru during 18451860, the era known as the apex of liberal electoral reform" (Peloso 1996, 186; see also Chiaramonti 1995; Demelas-Bohy 1995). 
The conservative reaction was implemented through the Constitution of 1860 and the corresponding voting regulations, which effected literacy, property, or tax requirements and dramatically decreased electoral turnout to 1 percent of the total population. Elections were held with some regularity, but voter registration still was rather informal. That opened paths to repeated violence on election day, local indigenous revolts, and persistent civil conflicts. A more stringent register of electors was established in 1892 , followed three years later by new electoral regulations reinforcing literacy tests as the exclusive means to enter the electorate. These measures opened the gate to the so-called aristocratic republic, a 20-year period in which elections were held regularly and peacefully with extremely low turnout (Basadre 1980; Aguila Peralta 1994; Chiaramonti 2000; Muncke 2001).

A new attempt to establish broad voting rights for political elections started in 1956. Although the legal requirement of literacy and the demobilizing effects of voluntary registration and compulsory vote were maintained, participation increased again to two-figure percentages of the total population. The subsequent success of left-populist candidates triggered several military interventions, leading to the establishment of a new dictatorship in 1968.

\section{Stabilizing Demobilization}

Argentina, Colombia, Mexico, and Peru began with broad voting rights and repeatedly restricted them after a number of violent conflicts. Other countries, in contrast, began with a very reduced electorate and slowly broadened it, thereby obtaining higher political stability during relatively long periods. To illustrate this alternative pattern-which better corresponds to some historical periods in Brazil and Chile-we focus again on certain institutional rules with a strong influence on electoral results, especially the restriction of voting rights by requiring economic or literacy qualifications and the slow, gradual enlargement of the electorate over the long term, as well as on certain procedures prone to demobilize electors (such as open ballot and electoral fraud). Again, the following qualitative statements are supported by and can be checked with the more precise data given in table 1.

Brazil. The Imperial Constitution of Brazil adopted in 1824 highly restricted voting rights by means of the exclusion of slaves, who made up almost one-third of the population, and an income requirement, which was doubled in 1846. From that moment on, electoral participation was extremely low, although it increased gradually and most visibly during the 1870 s. New restrictions were introduced in the 1880 s and with the establishment of the republic in 1891. Most prominently, the potential broadening of the electorate created by the abolition of slavery was halted by the requirement of literacy tests. Actually, in the 1880 s, the number of slaves had decreased to about 5 percent of the population, while the vast 
majority of the adult male population was illiterate, and therefore was excluded from voting by the new regulation. Brazil thus had a very long period-more than one hundred years-with high degrees of political stability and without major violent conflicts. Like other comparable though less durable nondemocratic regimes holding regular elections, however, its stability was based on an extremely restricted franchise, as well as on a practice of open ballot, the absence of political competition, and electoral fraud (Porto 1989; Graham 1990, 1995; Roett 1992; Wieseborn 1995; Leal 1997, Mainwaring 1999).

In the following period, by contrast, more rapid enlargements of the electorate produced-also consistent with our general hypothesis-a number of political clashes. Broader voting rights were established, after some steady pressure from new and excluded groups, by the New Republic led by Getulio Vargas. The electoral regulations established in 1932 gave voting rights to all men 18 years old, plus optional voting rights for those 16 years old, and introduced compulsory vote and secret ballot. As might be understood from the general perspective presented in this article, this was a very short and unsuccessful experience. While turnout increased, political competition polarized around the far-right Integralists and the far-left Communists, provoking frequent violent clashes before the establishment of a dictatorship in 1937.

A new democratic experience started in 1945, including voting rights for women, compulsory registration of voters, and a reduction of coercion and fraud. Electoral participation expanded rapidly, up to 18 percent of the total population. But plurality rule permitted the election of minority extreme presidents and favored increasing political polarization, which again preceded a military coup and the corresponding dictatorship in 1904. Conversely, and as in its own remote past, the present Brazilian democratic experience also came in somehow gradually in the late 1970 s and early 1980 s. Literacy ceased to be a formal requirement for access to voting rights only as late as 1985; but although literate electors are legally required to vote, abstaining is still optional for illiterates.

Chile. The first elections in Chile after 1822 and the Constitution of 1828 restricted the potential electorate by requiring a certain amount of income. After 1833, the requirements for voting included income or property, to which literacy was added in 1842. As in many countries in the region, the practice of open ballots, the absence of political competition, and fraud characterized most elections in the second third of the nineteenth century. In 1874 a new regulation was introduced that dropped the economic requirements, but literacy became a well-established condition for obtaining voting rights (Campos Harriet 1984).

The suppression of economic requirements for access to the vote has encouraged some authors to assert that "democracy" already existed in Chile in the last fourth of the nineteenth century. It is 
interesting to note, however, that the very law that introduced alternative literacy requirements clarified the lawmakers' intention not to significantly enlarge the electorate, since "it was presumed by right that whoever can read and write has the income required by the law." Actually, more than two-thirds of adult men were illiterate at the time, and therefore were automatically excluded from the franchise. Indeed, the proportion of voters out of the total population increased only from 2 to about 5 percent during the following four decades. Continuing very low levels of turnout, barely achieving 10 percent of the total population, characterized the longlasting new political regime established in 1925 (Valenzuela 1985, 1996, 2000).

From the late nineteenth century to the mid-twentieth century, Chile enjoyed high political stability, but at the cost of relatively low electoral participation. Only in the 1950 s did the electorate of men and women begin to increase rapidly, eventually to more than 30 percent of the total population. But the presidential electoral system, which implied a second round in Congress when no candidate obtained a majority of popular votes but was, in practice, applied in favor of the plurality winner, led to the election of extreme, minority winners facing majority opposition. The immediate outcome was social clash, a military coup, and the establishment of a bloody dictatorship in 1973. Illiterates could vote for first time as late as in 1989 (when they had been reduced to about 5 percent of the adult population). But about onefifth of the voting-age population was still kept away from the electoral census by the mechanism of voluntary registration, which is scheduled to be replaced with automatic registration for the first time for the presidential election to be held in 2005.

\section{CONCLUDING COMMENTS}

In the previous pages, the relation between voting rights, electoral participation, and political stability, with strong implications for Latin America, has been discussed with the help of a formal model and several empirical illustrations. First, the hypothesis was presented that sudden enlargements of the electorate may lie behind high levels of political instability. The formal analysis found that the potential degree of instability, as measured by the set of winning positions against the initial status quo or win-set, increases more than proportionally with the distance among voters' preferences and even more under exclusive electoral rules, such as plurality rule, that were most common in the past. In contrast, strategies such as the gradual allocation of voting rights to different groups able to produce successive moderate winners at different stages, or the inclusion of groups with intermediate preferences regarding the incumbent voters, can limit instability or even reinforce the stability of the status quo. 
Second, calculations of proportions of voters out of total population for the six largest Latin American countries in different periods were provided. With the help of these quantitative findings, this study sketched a historical survey to identify different patterns of political stability and instability in different countries and periods. Reviewing a number of illustrative cases, we remarked that plurality rule, indirect elections, and other exclusive electoral regulations that were widely used in the past in Latin American countries for both congressional and presidential elections tended to create minority, unpredictable, and shifting winners. Under these rules, certain enlargements of the electorate by the sudden introduction of broad voting rights tended to produce highly innovative, unexpected, biased outcomes, which could trigger negative reactions from defeated incumbent leaders and rulers and from other multiple losers against the new winners, as well as against the institutional rules that permitted such results.

A basic assumption in the present interpretation is that unexpected and biased electoral outcomes can foster leaders' and citizens' rejection of the corresponding electoral institutions and political regimes that produce such outcomes. Thus, certain experiences of sudden enlargement of the electorate have preceded significant turmoil, political crises, and regime changes. Following the same argument, however, other processes guided by a gradual or very slow introduction of new voters into the electorate and the enforcement of demobilizing institutional mechanisms have been able to support relatively longer periods of political stability.

Two basic historical patterns thus have been identified in the region. The first includes significant political experiences in countries such as Argentina, Colombia, Mexico, and Peru-which could be compared to those in some Latin European countries, such as France, Italy, and Spain-in which very broad suffrage rights were established at early stages. High levels of conflict and regime instability, including a number of dictatorships, characterize long historical periods for the countries in this group.

The second pattern better corresponds to certain periods in countries such as Brazil and Chile, where gradual enlargements of the electorate prevented sudden, dramatic shifts in electoral outcomes from occurring with the same high frequency as in other countries in the region. Gradual voting rights strategies and the corresponding trajectories with small electorates are somehow comparable to those in Britain and the United States in a very long-term evolution, although not always by the same means or with the same continuity. It should be remembered that although Britain did not achieve two-digit percentages of voters out of the total population until the end of the nineteenth century, in the United States some significant restrictions on voting rights for African Americans were maintained, especially in southern states, until the 1960s. In Latin America, this pattern involved the maintenance of highly restrictive voting regulations until the late decades of the twentieth century, especially the requirement of 
literacy tests, which, in the regional context, appears to have been a more effective exclusionary mechanism than the economic requirements of property or taxes. By excluding large sectors of society from political participation, the countries in this group experienced relatively long periods without major violent conflicts, and some political and regime stability.

In comparison with frail or restrictive political experiences in the past, during the most recent processes of democratization in Latin America, several institutional formulas favoring more inclusive and stable developments have been adopted. They include relatively inclusive electoral rules favoring wide acceptance of electoral results, such as proportional representation for the single or lower chamber of Congress, which creates multiple winners and prevents an absolute winner from holding a majority of seats without the support of a majority of voters. Latin America's presidential regimes, however, make electoral inclusiveness more difficult to achieve than the typical Western European parliamentary regimes, because no electoral rule producing a single winner, like those required for choosing a president, can guarantee that the winner will have absolute majority support of voters' first preferences. Nevertheless, majority or qualified-plurality rules with a second round-as most countries in the region are using in the present period-may significantly diminish the opportunities for extreme or minority candidates with strong majority opposition to win, as had frequently happened in the past in elections held by electoral college or by simple plurality rule. Recent democratic regulations also include, in virtually all countries, direct elections, secret ballot, and the establishment of independent electoral authorities to prosecute fraud, which tend to favor electors' participation.

Democratic stability does not depend only on institutional formulas, but also on other social variables (which could be operationalized partly as distances among the groups of voters in the model). Together with other factors, however, more inclusive institutional formulas, such as those just mentioned regarding the most recent democratic periods in Latin America, can favor relatively high levels of electoral participation and, at the same tine, lower the risks of provoking political and social clashes between losers and unaccepted winners. Thus, recent institutional reforms can help to explain the visible reduction of political and regime instability in the region in comparison with previous historical periods. 


\section{NOTES}

I am grateful above all to Bianca Heredia, in general for great companionship and in this case also for very helpful guidance in the Latin American labyrinth. I also enjoyed discussing this material with historians, in spite of methodological and substantive disagreements; especially Antonio Annino.

1. The argument presented in this article differs from the interpretation that if "the distribution of votes among parties changes only slowly after each extension of suffrage, [it implies] that even when suffrage is highly restricted, divergent interests are being represented," as formulated by Adam Przeworski and his coauthors $(2000,34)$. Conversely, here it is assumed that when suffrage is highly restricted, most people's interests are excluded from representation and political clecisionmaking. It is also held that if certain extensions of suffrage do not change distribution of votes among parties as dramatically as could be expected from the disparity of new voters' preferences regarding the incumbents, this outcome can result from the restrictive role of certain institutional mechanisms. 


\section{REFERENCES}

Aguila Peralta, Alicia del. 1994. Callejones y mansiones. Espacios de opinion publica y formas de action politico en Lima: el funcionamiento de una democracia restringida (1895-1919). Master's thesis. Mexico City: Facultad Latinoamericana de Ciencias Sociales (FLACSO). Alonso, Paula. 1996. Voting in Buenos Aires, Argentina, Before 1912. In Posada-Carbo 1996. 181-200. Annino, Antonio, ed. 1995. Historia de las elecciones en Iberoamerica, siglo XIX. Mexico City: Fondo de Cultura Economica. 1996. The Ballot, Land and Sovereignty: Cadiz and the Origins of Mexican Local Government, 1812-1820. In Posada-Carbo 1996. 61-86.

Ansaldi, Waldo. 1993. ¿Un caso de nomenclatures equivocadas? Los partidos politicos clespues de la Ley Saez-Pena, 1916-1930. In Argentina en la paz de dosguerras 1914-1945, ed. Ansaldi, Alfredo R. Pucciarelli, and Jose Villarreal. Buenos Aires: Biblos.

Arosemena, Justo. 1878. Estudios constitutionals sobre los gobiernos de la America Latina. 2 vols. Paris: Libreria Espanola y Americana de E. Denne.

Basadre, Jorge. 1980. Elecciones y centralismo en Peru. Apuntes para un esquema historico. Lima: Universidad del Pacifico.

Becerra, Ricardo, Pedro Salazar, and Jose Woldenberg. 2000. La mecanica del cambio politico en Mexico: elecciones, partidos y reformas. Mexico City: Cal y Arena.

Bethell, Leslie ed. 1993. Argentina Since Independence. New York: Cambridge University Press.

Botana, Natalio. [1977] 1998. El orden conservador. La politica argentina entre 1880y 1916. Buenos Aires: Sudamericana.

Brandenburg, Frank. 1964. The Making of Modern Mexico. Englewood Cliffs: Prentice-Hall.

Bushnell, David. 1993. The Making of Modern Colombia: A Nation In Spite of Itself. Berkeley: University of California Press.

Campos Harriet, Fernando. 1984. El sufragio en Chile: 1810-1980. Revista Politica 6 (Chile).

Canton, Dario. 1973. Elecciones y partidos politicos en la Argentina. Historia, interpretation y balance. Buenos Aires: Siglo XXI.

Canton, Dario, Jose L. Moreno, and Alberto Ciria. 1990. Argentina. La democracia constitutional y su crisis. Buenos Aires: Paidos.

Chavarri Sidera, Pilar. 1988. Las elecciones de diputados a las cartes generales y extraordinarias (18101813). Madrid: Centro de Estudios Constitucionales. 
Chiaramonte, Jose Carlos. 1995. Vieja y nueva representation: Ios procesos electorales en Buenos Aires, 1810-1820. In Annino 1995. 19-64.

Chiaramonti, Gabriella. 1995. Andes o nation: la reforma electoral de 1896 en Peru. In Annino 1995. 31546.

2000. Construir el centro, redefinir al ciudadano: restriction del sufragio y reforma electoral en el Peru de finales del siglo XIX. In Malamud 2000. 230-61.

Cibotti, Ema. 1995. Sufragio, prensa y opinion publica: las elecciones municipales de 1933 en Buenos Aires. In Annino 1995. 143-76.

Colomer, Josep M. 1998. Mexico: democracia a medias. Claves 87: 41-49. 2001. Political Institutions: Democracy and Social Choice. New York: Oxford University Press. Cossio Villegas, Daniel, ed. 1976. Historia general de Mexico. Mexico City: El Colegio de Mexico. Dahl, Robert A. 1971. Polyarchy: Participation and Opposition. New Haven: Yale University Press. Deas, Malcolm. 1996. The Role of the Church, the Army and the Police in Colombian Elections, c.18501930. In Posada-Carbo 1996. 163-80.

Demelas-Bohy, Marie-Danielle. 1995. Modalidades y significacion general de elecciones generales en los paises andinos, 1813-1814. In Annino 1995. 291-314.

Demelas-Bohy, Marie-Danielle, and Francois-Xavier Guerra. 1996. The Hispanic Revolutions: The Adoption of Modern Forms of Representation in Spain and America, 1808-1810. In Posada-Carbo 1996. 33-60.

Di Tella, Torcuato S. 1994. Politica nacional y popular en Mexico 1820-1847. Mexico City: Fondo de Cultura Economica.

Emmerich, Gustavo Ernesto. 1985. Las elecciones en Mexico, 1808-1911: ¿sufragio efectivo? ¿no reeleccion? In Las elecciones en Mexico. Evolucion y perspectivas, ed. Pablo Gonzalez Casanova. Mexico City: Siglo XXI. 41-67.

Gonzalez Casanova, Pablo. 1967. La democracia en Mexico. Mexico City: Era.

Graham, Richard. 1990. Patronage and Politics in Nineteenth-Century Brazil. Stanford: Stanford University Press.

1995. Formando un gobierno central: las elecciones y el orden monarquico en el Brasil del siglo

XIX. In Annino 1995. 347-80.

Guerra, Francois-Xavier. 1985. Mexique de I'Ancien Regime a la Revolution. Paris: L'Harmattan. Huntington, Samuel P. 1968. Political Order in Changing Societies. New Haven: Yale University Press. International Foundation for Election Systems (IFES). Washington, DC.

International Institute for Democracy and Electoral Assistance (IDEA). 1997. Voter Turnout from 1945 to 1997: A Global Report on Political Participation. Stockholm: IDEA. 
2002. Voter Turnout Since 1945: a Global Report. Stockholm: IDEA.

Katz, Richard S. 1997. Democracy and Elections. New York: Oxford University Press.

Krauze, Enrique, ed. 1984. Daniel Cossio Villegas. El historiador liberal. Mexico City: Fondo de Cultura Economica.

Leal, Victor Nunes. [1949] 1997. Coronelismo, enxada e voto. O municipio e o regime representative no Brasil. Sao Paulo: Nova Frontera.

Luna, Felix. 1988. Fuerzas hegemonicas y partidos politicos. Buenos Aires: Sudamericana.

Mainwaring, Scott P. 1999. Rethinking Party Systems in the Third Wave of Democratization: The Case of Brazil, Stanford: Stanford University Press.

Malamud, Carlos, ed. 2000. Legitimidad, representation y alternancia en Espana y America Latina: Ias reformas electorales (1880-1930). Mexico City: Fondo de Cultura Economica.

Meyer, Lorenzo. 1985. La revolution mexicana y sus elecciones presidenciales, 1911-1940. In Las elecciones en Mexico. Evolution y perspectivas, ed. Pablo Gonzalez Casanova. Mexico City: Siglo XXI. 6999.

Meyer, Michael C., and William L. Sherman. 1979. The Course of Mexican History. New York: Oxford University Press.

Mitchell, B. R. 1992. International Historical Statistics. New York: Stockton.

Muncke, Ulrich. 2001. Elections and Political Participation in Nineteenth-century Peru: The 1871-72 Presidential Campaign. Journal of Latin American Studies 33: 311-46.

Negretto, Gabriel, and Jose A. Aguilar. 2000. Rethinking the Legacy of the Liberal State in Latin America. Journal of Latin American Studies 32: 361-97.

Nohlen, Dieter. 1993. Enciclopedia electoral latinoamericana y del Caribe. San Jose, Costa Rica: Institute Interamericano cle Derechos Humanos.

Ochoa, Enrique C. 1987. The Rapid Expansion of Voter Participation in Latin America: Presidential Elections, 1845-1986. In Statistical Abstract of Latin America, ed. James W. Wilkie and David Lorey. Los Angeles: University of California Latin American Center Publications.

Payne, J. Mark, Daniel Zovatto G., Fernando Carrillo Florez, and Andres Allamand Zavala. 2002. Democracies in Development: Politics and Reform in Latin America. Washington, DC: Inter-American Development Bank.

Peloso, Vincent C. 1996. Liberals, Electoral Reform, and the Popular Vote in Mid-nineteenth-century Peru. In Liberals, Politics, and Power: State Formation in Nineteenth-Century Latin America, ed. Peloso and Barbara A. Tenenbaum. Athens: University of Georgia Press. 186-211. 
El pensamiento constitutional hispanoamericano hasta 1830. Compilation de constituciones nacionales y proyectos constitutionals. [1831] 1961. Caracas: Academia Nacional de la Historia.

Perry, Laurens Ballard. 1979. Juarez and Diaz: Machine Politics in Mexico. De Kalb: Northern Illinois University Press.

Political Database of the Americas. Washington, DC: Center for Latin American Studies, Georgetown University, Porto, Walter Costa, 1989. O voto no Brasil. Da colonia a 5a Republica. Brasilia: Senado Federal. Posada-Carbo, Eduardo. 1996. Elections Before Democracy: The History of Elections in Europe and Latin America. New York: St. Martin's Press. 1997. Limits of Power: Elections Under the Conservative Hegemony in Colombia, 1886-1930. Hispanic American Historical Review 77, 2: 245-79. 2000. Fraude al sufragio: la reforma electoral en Colombia, 1830-1930. In Malamud 2000. 208-

29.

Przeworski, Adam, Mike Alvarez, Jose Antonio Cheibub, and Fernando Limogi. 2000. Democracy and Development: Political Institutions and Material Well-Being in the World, 1950-1990. New York: Cambridge University Press.

Roett, Riordan. 1992. Brazil: Politics in a Patrimonial Society. Westport: Praeger.

Rokkan, Stein. 1970. Citizens, Elections, Parties: Approaches to the Comparative Study of the Processes of Development. New York: David McKay.

Rose, Richard et al., eds. 2000. International Encyclopedia of Elections. Washington, DC: Congressional Quarterly Press/Palgrave.

Sabato, Hilda. 1995. Elecciones y practicas electorales en Buenos Aires, 1860-1880. ¿Sufragio universal sin ciudadania politica? In Annino 1995. 107-42.

Scott, Robert E. 1964. Mexican Government in Transition. Urbana: University of Illinois Press. Ternavasio, Marcela. 1995. Nuevo regimen representative y expansion de la frontera politica. Las elecciones en el estado de Buenos Aires: 1820-1840. In Annino 1995. 65-106.

Valenzuela, J. Samuel. 1985. Democratizacion via reforma: la expansion del sufragio en Chile. Buenos Aires: IDES. 1996. Building Aspects of Democracy Before Democracy: Electoral Practices in Nineteenth-century Chile. In Posada-Carbo 1996. 223-57. 2000. La ley electoral de 1890 y la democratizacion del regimen politico chileno. In Malamud 2000. 130-61. 
Vanhanen, Tatu. 1975. Political and Social Structures. Part 1: American Countries, 1850-1973. Tampere, Finland: University of Tampere.

Warren, Richard. 1996. Elections and Popular Political Participation in Mexico, 1808-1836, In Liberals, Politics, and Power: State Formation in Nineteenth-Century Latin America, ed. Peloso and Barbara A. Tenenbaum. Athens: University of Georgia Press. 30-46.

Wieseborn, Marianne L. 1995. Elecciones en el Brasil 1880-1900: Bom Jardim y Afogados da Ingazeira (Pernambuco). Relacion del poder local con el poder estatal. In Annino 1995. 409-52.

Copyright Latin American Politics and Society Summer 2004 Provided by ProQuest Information and Learning Company. All rights Reserved 